\title{
COMPARATIVE ANALYSIS OF THE EFFECT OF WHITE AND RED TABLE WINES ON THE BRAIN OF WISTER RATS
}

\author{
${ }^{* 1}$ Kukoyi, A. J., ${ }^{2}$ Coker, T. A., ${ }^{3}$ Arowora, K. A., ${ }^{4}$ Ukperoro, J. E., ${ }^{5}$ Alabi, M. A. and ${ }^{6}$ Ishola, A. \\ ${ }^{* 1,2,3,4,5}$ Department of Biochemistry, Faculty of Pure and Applied Sciences, Federal \\ University Wukari, P.M.B. 1020, Wukari, Taraba State, Nigeria. \\ "Phone: +2348107903830 Email: ayobamikukoyi@yahoo.com,a.kukoyi@fuwukari.edu.ng
}

\begin{abstract}
The aim of this research was to investigate the possible effects of white and red table wine on the brain using Wister rats. Twenty-four (24) Wister rats weighing an average of $193 \mathrm{~g}$ were purchased and identified at the zoological department of the University of Ibadan, Ibadan, Nigeria. The rats were randomly assigned to four groups of six rats each. Red wine (12\% alcoholic content), white wine (12\% alcoholic content), ethanol $+\mathrm{H} 2 \mathrm{O}(12 \%)$ and distilled water (control), were administered orally and respectively for 10 days. Administration was done using syringe and tourniquets to each rat according to the $\mathrm{kg}$ body weight (10 $\mathrm{ml} / \mathrm{kg}$ body weight). The rats were later sacrificed and subjected to biochemical and brain homogenate analysis. The results show that the plasma and brain homogenate of rats administered White wines were significantly lower $(\mathrm{p}<0.05)$ than control for Total Cholesterol determination. Similarly, the plasma and brain homogenate of rats administered White wine were significantly lower $(\mathrm{p}<0.05)$ than control for Thiobarbituric Acid Reactive Substance (TBARS) determination. Meanwhile, other parameters like HDL-cholesterol, LDL-Cholesterol, Glutathione, Triglyceride, Total Protein, Uric acid and Creatinine were not significantly different from the control for plasma and homogenate analysis. In all, White wine was not found to express any trace of toxicity on the brain as opposed to Red wine. The study therefore shows that White wine are more healthy than red wines and as such when given an option between red and white, white wine should be preferred.
\end{abstract}

Keywords: alcohol, brain, cholesterol, white wine, red wine, homogenate, Wister rats, Thiobarbituric acid

LICENSE: This work by Open Journals Nigeria is licensed and published under the Creative Commons Attribution License 4.0 International License, which permits unrestricted use, distribution, and reproduction in any medium, provided this article is duly cited.

COPYRIGHT: The Author(s) completely retain the copyright of this published article.

OPEN ACCESS: The Author(s) approves that this article remains permanently online in the open access (OA) mode.

QA: This Article is published in line with "COPE (Committee on Publication Ethics) and PIE (Publication Integrity \& Ethics)". 


\section{INTRODUCTION}

White grapes are used for white wine production, though some are made with black grapes. No contact is made with the grape skin, hence no colour. Winemakers can also make white wine from black grapes; this is because the juice in most black grapes is usually clear. Popular white wines are Chardonnay, Pinot Grigio, Riesling Sauvignon Blanc etc. (Serafini et al., 1998) Red wines are made from Black or Red grapes. The main difference between red wines and others is the presence of the skin throughout the entire fermentation process (Serafini $e t$ al. ,1998).

Moderate alcohol consumption can reduce the incidence of mortality from cardiovascular Diseases (CHD). Most discoveries attribute the health benefits of red wine consumption to the alcohol and phenolic compounds present in it (Ginjom et al., 2011). Similarly, grape juice contains many of the same biologically active phenolic compounds found in red wine and may also contribute to the prevention of atherosclerosis and Parkinson's disease (Ribereau-Gayon, 2010).

Brain homogenate analysis is necessary in this research because, Montoliu and his colleagues claimed from their experimental findings that ethanol build up can interfere with brain functions (Montoliu et al.,2000). Actually, the decision to choose White wine emerged from the disappointing discoveries of potential dangers in Red wines (Kukoyi et al., 2018). This necessitated the reason for having various lower concentrations of Red Wine analyzed. Even at lower concentrations, Red Wines were still found to be potentially dangerous to the liver (Kukoyi et al., 2018)

This research is designed to determine the effects of Red wine and White wine consumption on the weight of rats, biochemical parameters of brain homogenate and plasma of rats, together with rat's lipid profile.

\section{MATERIALS AND METHODS EXPERIMENTAL DESIGN}

Twenty-four (24), seven (7) weeks old Wister rats weighing an average of 193g were purchased and identified in the zoological department of the University of Ibadan, Ibadan, Nigeria. The rats were randomly assigned to four (4) groups of six (6) rats each. Red wine (12\% alcoholic content), white wine (12\% alcoholic content), ethanol $+\mathrm{H}_{2} \mathrm{O}(12 \%)$ and distilled water, were administered orally, respectively for 10 days. Using syringe and tourniquets to each rat according to the $\mathrm{kg}$ body weight (10 $\mathrm{ml} / \mathrm{kg}$ body weight).

\section{PREPARATION OF SAMPLE FOR BIOCHEMICAL ANALYSIS}

After the treatment for 10 days the rats were sacrificed and blood samples were collected in plain plastic tubes. The brain was carefully removed using dissecting scissors from the animal and blotted on filtered paper, weighed and homogenized according to the procedure of Geetha (Geetha, 2011).

\section{DETERMINATION OF PARAMETERS}

Triglyceride (TG), Uric acid, Creatinine, Total protein (TP), Thiobarbituric Acid Reactive Substance (TBARS), Total Cholesterol, HDL and LDL-Cholesterol, Glutathione (GHS) and with brain homogenate were determined using the Kit method of Randox according to the principle explained by Geetha (Geetha, 2011). 


\section{STATISTICAL ANALYSIS OF OBTAINED DATA}

All obtained data were statistically evaluated using SPSS software. Hypothesis testing methods included one-way analysis of variance (ANOVA) followed by Duncan's Multiple Range Test. P values of less than 0.05 were considered to indicate statistical significance. All the results were expressed as mean \pm SEM.

\section{RESULTS}

\section{RESULT OF RATS WEIGHT}

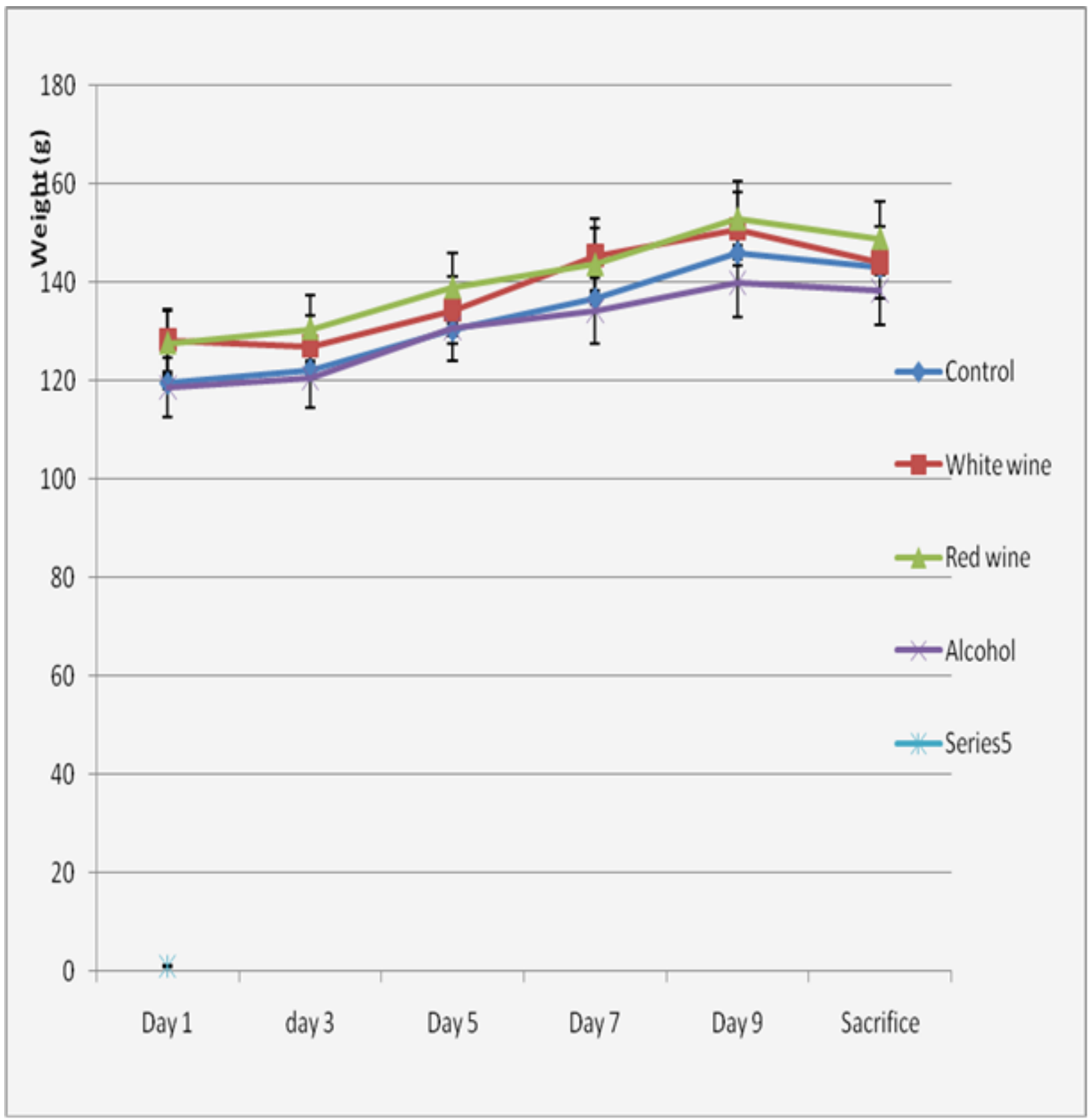

Figure 1: Weight of Rats 


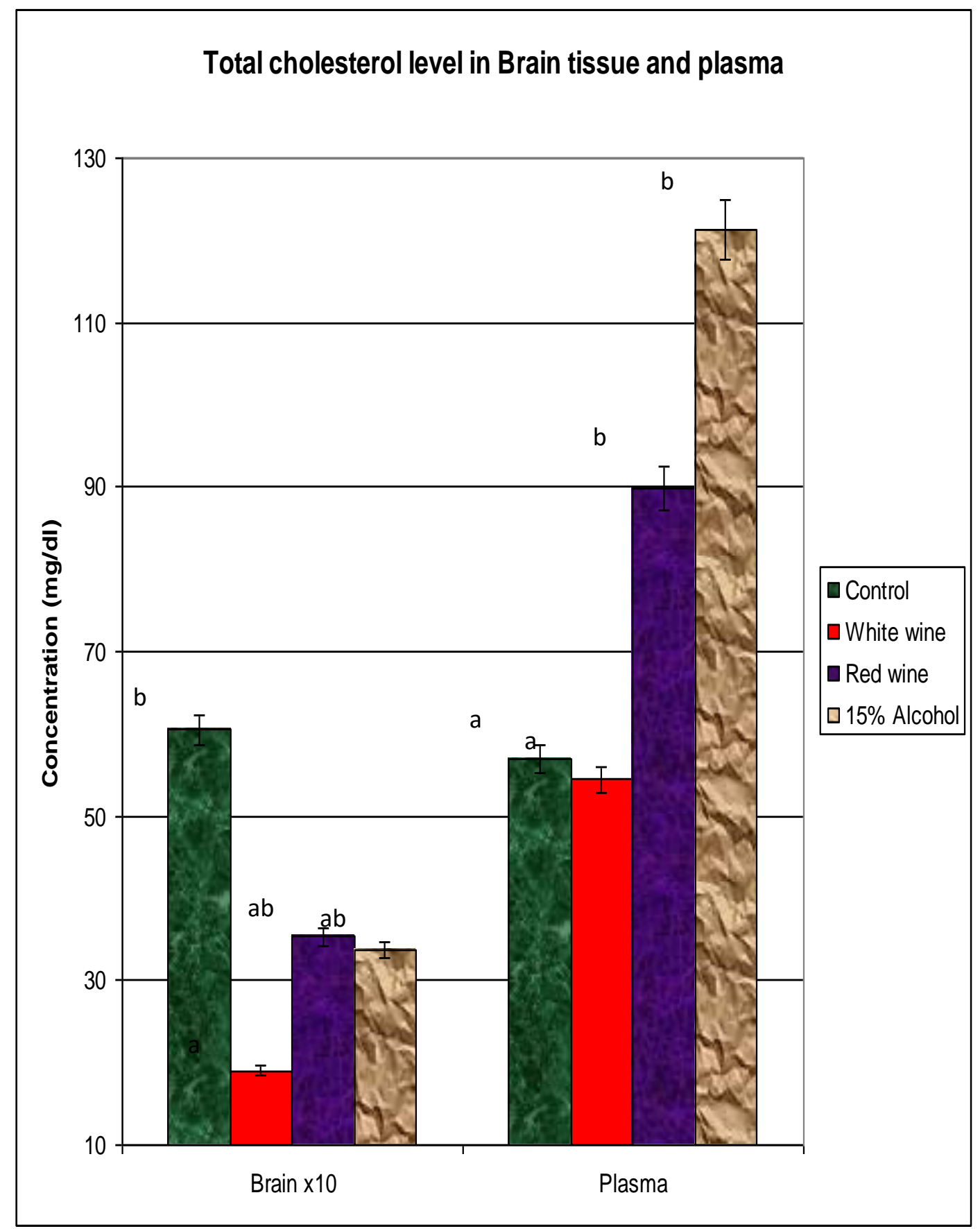

Figure 2: Result for Total Cholesterol of Plasma and Brain homogenate 


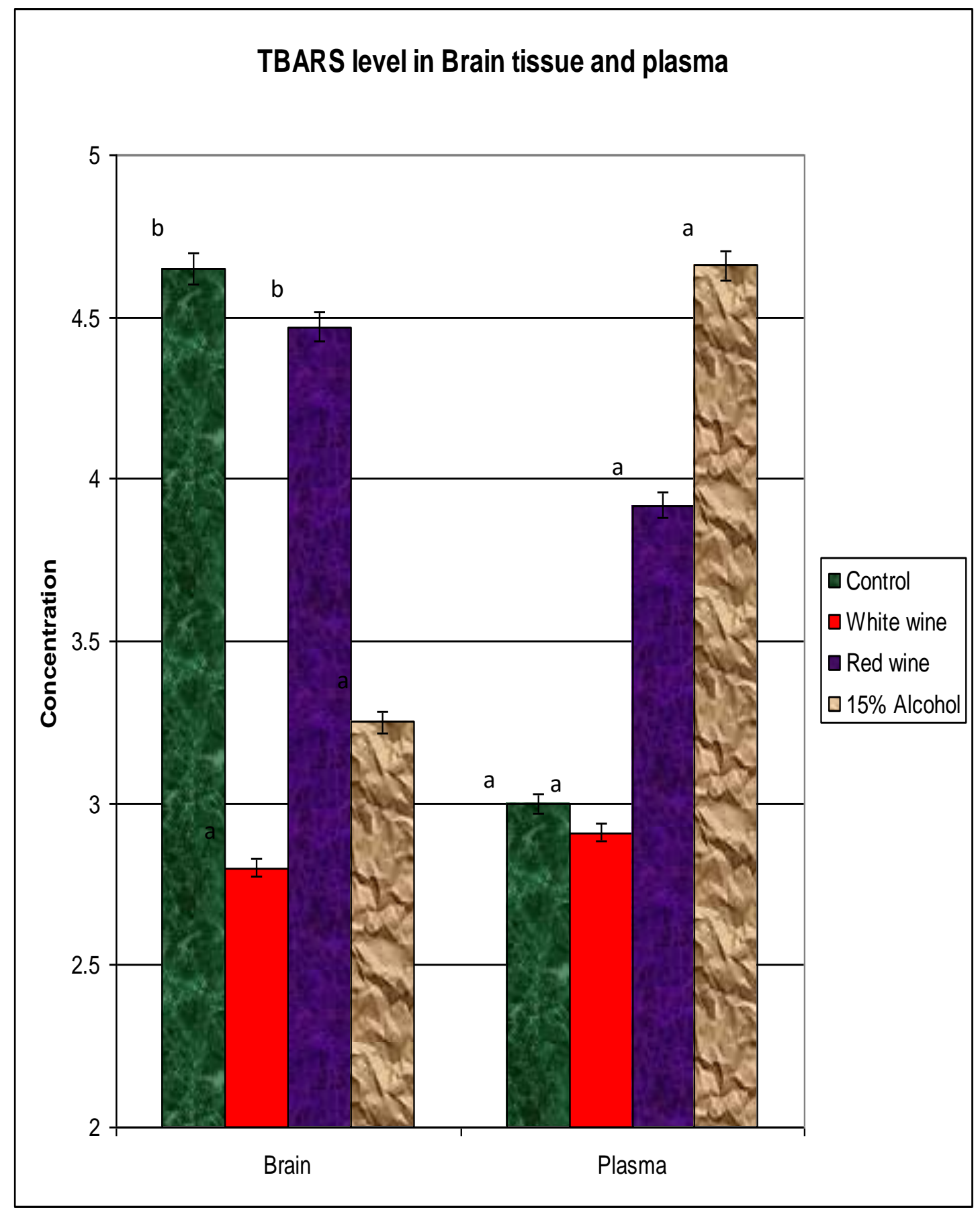

Figure 3: Result for TBARS of Plasma and Brain homogenate

Values are expressed as mean \pm SEM. Mean values are compared using One-Way ANOVA. Level of significance was evaluated using Duncan's Multiple Range Test (DMRT) at $\mathrm{P} \leq 0.05$. Bars of the same section with different letters are significantly different $(\mathrm{P}<0.05)$. 
Table 1: Homogenate brain analysis

\begin{tabular}{lllll}
\hline PARAMETERS & CONTROL & WHITE WINE & REDWINE & ETHANOL \\
\hline HDL-CHOL & $196.28 \pm 144.59^{\mathrm{a}}$ & $75.19 \pm 28.56^{\mathrm{a}}$ & $180.00 \pm 46.90^{\mathrm{a}}$ & $187.05 \pm 29.81^{\mathrm{a}}$ \\
LDL-CHOL & $527.17 \pm 291.56^{\mathrm{a}}$ & $184.28 \pm 49.88^{\mathrm{a}}$ & $355.33 \pm 151.52^{\mathrm{a}}$ & $209.27 \pm 115.14^{\mathrm{a}}$ \\
& & & $45.18 \pm 0.28^{\mathrm{a}}$ \\
GHS HOMO & $41.44 \pm 2.52^{\mathrm{a}}$ & $38.88 \pm 2.85^{\mathrm{a}}$ & $41.47 \pm 2.44^{\mathrm{a}}$ & \\
& & & \\
TG-HOMO & $211.40+16.87^{\mathrm{a}}$ & $164.45 \pm 20.07^{\mathrm{a}}$ & $205.85 \pm 22.58^{\mathrm{a}}$ & $203.77 \pm 21.83^{\mathrm{a}}$ \\
\hline
\end{tabular}

Table 2: Plasma analysis

\begin{tabular}{|c|c|c|c|c|}
\hline PARAMETERS & CONTROL & WHITEWINE & REDWINE & ETHANOL \\
\hline TOTAL PROT & $19.40 \pm 2.10^{\mathrm{ab}}$ & $23.30 \pm 2.09^{b}$ & $17.30 \pm 1.82^{\mathrm{ab}}$ & $15.48 \pm 2.48^{\mathrm{a}}$ \\
\hline URIC ACID & $6.07 \pm 1.60^{\mathrm{a}}$ & $13.66 \pm 2.08^{\mathrm{b}}$ & $6.48 \pm 1.72^{\mathrm{a}}$ & $4.69 \pm 0.89^{a}$ \\
\hline GSH & $22.64 \pm 6.92^{\mathrm{a}}$ & $28.63 \pm 3.70^{\mathrm{a}}$ & $15.51 \pm 6.07^{\mathrm{a}}$ & $31.56 \pm 12.64^{\mathrm{a}}$ \\
\hline TG & $153.88 \pm 57.14^{\mathrm{a}}$ & $96.25 \pm 2.52^{\mathrm{a}}$ & $89.98 \pm 1.27^{\mathrm{a}}$ & $278.26 \pm 47.49^{b}$ \\
\hline CREATININE & $4.28 \mathrm{E}-02 \pm 1.22 \mathrm{E}-02^{\mathrm{a}}$ & $5.73 \mathrm{E}-02 \pm 1.50 \mathrm{E}-02^{\mathrm{a}}$ & $3.98 \mathrm{E}-02 \pm 1.81 \mathrm{E}-02^{\mathrm{a}}$ & $1.93 \mathrm{E}-02 \pm 4.12 \mathrm{E}-03^{\mathrm{a}}$ \\
\hline
\end{tabular}

\section{DISCUSSION}

The increases observed in weight of rats used in this analysis were not statistically significant $(\mathrm{P}>0.05)$. In the plasma, White wine was found to significantly lower $(\mathrm{p}<0.05)$ the extent of Total cholesterol than the control. While Red wine and Ethanol were significantly higher than control. In the same proportion, White wine again is seen to significantly lower $(\mathrm{p}<0.05)$ the extent of total cholesterol than the control in the Brain tissue homogenate. In the case of TBARS, white wine all over again was significantly lower than control for both the plasma and Brain homogenate. Ultimately, Triglyceride (TG), Uric acid, Creatinine, Total protein (TP), HDL and LDLCholesterol and Glutathione (GHS) considered for both plasma and brain homogenate were not significantly different $(\mathrm{P}>0.05)$ from the control.

In summary rats administered White wines were significantly lower $(\mathrm{p}<0.05)$ than control for Total Cholesterol and TBARS for both plasma and homogenate analysis. We should remember that TBARS is for lipid peroxidation. This discovery may help explain the observation discovered by Kukoyi and his fellow researchers, who found out that rats administered Red wine and White wine behaved identically. Both wines had potential adverse effect on the liver. 
Moreover, they possess good lipid profile, antibacterial activity and preserves heart's histological state (Kukoyi et al., 2018). Meaning the positive effect of white wines on the lipid profile, antibacterial activity and heart's histological state can only be achieved if taken occasionally and moderately. Some studies suggest that consumption of $250-400 \mathrm{ml}$ Red wine per day is beneficial in preventing cardiovascular diseases (Rekha et al., 2015) Histological figures of another research show that all the wines do not have adverse or destructive effect on the histological architecture of the brain for the period of administration.

Confidently, the result of the brain homogenate analysis proves the histological result right. Finally, the Resveratrol content of the White wine is of additional advantage because it improves memory performance, glucose metabolism and hippocampal functional connectivity in older adults (Witte et al.,2014).

\section{CONCLUSION}

This research has thrown more light into the conflicting view of wines being both dangerous and beneficial. The study compared Red wine and White wine together with ethanol + water (12\%) which is the ethanol control. It is also noteworthy that the tissue of focus this time is the brain not the liver. White wine was not found to be potentially dangerous at all to the brain when consumed moderately. The study also shows that White wine are more healthy than red wines and as such when given an option between red and white, white wine should be preferred. 


\section{REFERENCES}

Kukoyi, A. J. Arowora, K. A., Imo, C., Mayel, M. H. and Sarduana, S. B. (2018): Effects of Various Volumes of Red Wine on Liver Function of Male Wistar Rats. FUW Trends in Science \& Technology April, 2018, Vol. 3 No. 1 pp. 79 - 82

Geetha, D. K. (2011). Practical Biochemistry. Jaypee Brothers Medical Publishers (P) Ltd, UK.

Ginjom, I., D'Arcy, B., Caffin, N., Gidley, M. (2011) Phenolic compound profiles in selected Queensland red wines at all stages of the wine-making process Food Chem. 2011;125(3):823-834.

Kukoyi, A. J., Arowora, K. A., Adegbite, O. S., Akinsanya, Y. I. and Ciroma, I. J. (2018) Protective Effects and Dangers of Wines on the Heart andLiver. Health Sciences Research. Vol. 5, No. 1, pp. 29-34.

Montoliu, C., Valles S. and Reneu-piqueras J. (2000). Ethanolinducedoxygen radical formation and lipid peroxidation in rat brain. Effect of chronic alcohol consumption. Journal of Neurochemistry 63: $1855-1862$

Rekha, B. and Pasad. M., S. (2015) A review on benefits of resveratrol on health and diseases especially Cardiovascular Diseases International Journal of Current Advanced Research Vol 4, Issue 12, pp 537-544.

Ribereau-Gayon P. (2010) Centers for Disease Control and Prevention. Leading Causes of Death. Available at: http://www.cdc.gov/nchs/fastats/lcod.htm. Accessed December 14, 2010.

Serafini, M., Maiani, G. and Ferro-Luzzi., A. (1998). Alcohol-free red wine enhances plasma antioxidant capacity in humans. Journal of Nutrition.128:1003-1007.

Witte, V., A., Kerti, L., Daniel, S. argulies and Agnes F. (2014). effects of resveratrol on memory performance, hippocampal functional connectivity, and glucose metabolism in healthy older adults. The Journal of Neuroscience; 34 (23): 7862-7870. 